\title{
Evaluation of Sewy Date Palm Productivity under Different Climatic Conditions
}

\author{
Ahmed-Amen, Kamelia I.; R.A.A. Mostafa; Doaa Sh. El- Azab and A.M. Ali ${ }^{*}$ \\ Pomology Department, Faculty of Agriculture, Assiut University, Assiut, Egypt \\ *E-mail: ahmedali171090@yahoo.com
}

Received on: $11 / 1 / 2018$

Accepted for publication on:16/1/2018

\begin{abstract}
This study was carried out during three successive seasons of 2015, 2016 and 2017 to evaluate yield and fruit quality of Sewy date palm cultivar grown under Aswan, El-Kharga, Assiut and Al-Dakhla climatic conditions. The data revealed that, Sewy cultivar grown in El-Kharga and Al-Dakhla which had higher temperature and lower relative humidity (R.H.) gave the higher bunch weight and total yield compared with those grown in Assiut which had lower temperature and higher R.H.

High temperature and low R.H. from March to October caused earlier fruit maturity in Aswan and El-Kharga with about three to four weeks than in Assiut, whereas the earlier harvest date under Al-Dakhla about two weeks than in Assiut.

Fruit dimensions, weight and flesh percentage recorded the greatest values in Assiut and Al-Dakhla as compared with other studied locations. At high temperature and low R.H. under Aswan and El-Kharga conditions, the pulp of Sewy dates had higher TSS and total sugar content whereas it had less moisture content than pulp of those produced in the other localities.

No significant differences were observed in chemical fruits quality that produced under El-Kharga and Al-Dakhla locations. It is evident from the foregoing results that the climatic conditions of Al-Dakhla and El-Kharga are ideal climatic conditions for the cultivation and production of Sewy date palm.
\end{abstract}

Keywords: Date palm, Evaluation, Climatic conditions, Yield, Fruit quality.

\section{Introduction}

Date palm (Phoenix dactylifera $L$.$) is considered an old fruit tree in$ many countries all over the world. Dates are a high energy food and rich with carbohydrate (60-70\% sugar, mainly glucose and fructose) serve as an important food (Wrigley, 1995). Date palm fruits had a stable food for the population of the Middle East and North Africa for thousands of years. Date palm grows successfully throughout Egypt from the relatively cool coast of the Mediterranean Sea up to the burning heat of Aswan Governorate.
Date palm fruits are one of the most important export fruit crops in Egypt, where they are harvested and marketed at three stages are Khalal (bisr), Rutab and Tamar (Kassem 2012). Date palm cultivars are of three main types according to its fruit moisture content and they are classified soft, semi-dry and dry cultivars (Selim et al., 1968). Sewy dates is one of the important semi dry variety that's suitable for packaging, processing and storage, it is considered to be one of the most important varieties for local market and export. It is located in New Valley, Al Bahareya 
Oasis, Al Fayoum and Al Giza Governorates (Jaradat and Zaid, 2004).

The yield and dates quality are variable due to various factors such as cultivar, region, climate, fertilization and cultural practices. Climatic adaptions are of primary importance. The perspective date growers should give careful attention to the selection of cultivars likely to succeed in his locality (Rygg 1971, Nixon 1978, Abdalla et al., 1991 \&1996 and AlRawahi et al., 2005). Several investigators studied the effect of agroclimatic conditions on yield and date quality (Rygg 1971, Abdalla et al., 1990, 1991, 1996, Mohamed et al., 2004). Such study will help to choose regions that are characterized by climatic conditions suitable for the highest productivity.

Therefore, the main objective of this current study is to evaluate the effect of various climatic conditions on fruiting of Sewy date palm, to select the best producing area.

\section{Materials and methods}

The present study was carried out during the three successive seasons of 2015, 2016 and 2017 on Sewy date palm grown at four different regions in Upper Egypt. These regions included Aswan, El-Kharga Oasis, Assiut and Al-Dakhla Oasis.
Climatic condition, especially temperature degree and relative humidity are known in Table (1).

Each region was represented by 5 palms at the same age nearly and in full production stage. Bunches were thinned to 10 per palm by removing excess earliest, latest and smallest ones. The inflorescences of the palms under this study were manually pollinated by one source of pollen. They were pollinated during first week of March in all seasons of study at Aswan followed by El-Kharga and AlDakhla Oasis of the third week of March, while in Assiut pollination was carried out on first week of April.

The experiment was arranged in a complete randomized block design including four treatments (regions) with five replications, one palm each. For yield, bunch and fruit characteristics, the harvest took place at the peak of full color stage (before it's quite ripe). Fruit retention, the average bunch weight and yield per palm were recorded. The percentage of fruit retention was calculated using the following equation:

Fruit retained $\%=\frac{\text { Total number of retained fruits/strand }}{\text { number of retained fruit/strandand number offlowerscars }} \times 100$ 
Table 1. Average high temperature and high relative humidity in Aswan, ElKharga, Assiut and Al-Dakhla in 2015, 2016 and 2017.

\begin{tabular}{|c|c|c|c|c|c|c|c|c|c|c|c|c|c|}
\hline \multirow{2}{*}{\multicolumn{2}{|c|}{ Month }} & \multicolumn{3}{|c|}{ Aswan } & \multicolumn{3}{|c|}{ El-Kharga } & \multicolumn{3}{|c|}{ Assiut } & \multicolumn{3}{|c|}{ Al-Dakhla } \\
\hline & & 2015 & 2016 & 2017 & 2015 & 2016 & 2017 & 2015 & 2016 & 2017 & 2015 & 2016 & \begin{tabular}{|l|}
2017 \\
\end{tabular} \\
\hline \multirow{2}{*}{ Mar. } & & & & & & & & & & & & & \\
\hline & & & & & & & & & & & & & \\
\hline \multirow{2}{*}{ April } & & & & & & & & & & & & & \\
\hline & & & & & & & & & & & & & \\
\hline \multirow{2}{*}{ May } & & & & & & & & & & & & & \\
\hline & & & & & & 26.67 & & & & & & & 2.95 \\
\hline & & & & & & & & & & & & & \\
\hline & & & & & & & & & & & & & .6 \\
\hline & & & & & & & & & & & & .54 & 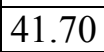 \\
\hline & & & & & & & & & & & & & \\
\hline \multirow{2}{*}{ Aug. } & & & & & & & & & & & & & \\
\hline & & & & & & & & & & & & & 1.82 \\
\hline \multirow{2}{*}{ Sep } & & & & & & 37.76 & & & 34.80 & 35 & 26 & 6.76 & 37.78 \\
\hline & & & & & & & & & 00 & & & 6.03 & $48.4 \mathrm{C}$ \\
\hline & & .00 & 37.3 & 4 & 5.00 & 34.16 & 59 & .67 & 51 & 29.96 & 1.77 & 2.67 & 33.4 \\
\hline & & & 39. & & & & & & & & 22 & 0.03 & 1.72 \\
\hline & & & & & & & & & & & 96 & 1.06 & 6.5 \\
\hline & & 30.75 & 30.09 & & 31.20 & 33.67 & & & 62.75 & 59.93 & 45.44 & 43.91 & 47.0 \\
\hline
\end{tabular}

According to Meteorology Organization

Samples of 50 fruits were picked at random from each palm to determine some physical and chemical fruit properties (fruit weight, flesh percentage, fruit length and fruit diameter.

Dates moisture content was determined by drying the samples at $70^{\circ} \mathrm{c}$ until constant weight according to AOAC, (1985). The moisture content percentage was calculated using the following equation:-

Moisture $\%=$

weight before drying-weight after drying $\times 100$ weight before drying

Sugar contents, were determined according to the methods of AOAC, (1985). Total soluble solids (TSS) were estimated using a hand refractometer.

Total phenols: date fruits $(1 / 2$ gram) were extracted by $30 \mathrm{ml}$ etha- nol and water $(1: 1 \mathrm{v} / \mathrm{v})$. The mixture was stirred for three hrs. at room temperature and then centrifuged at $3000 \mathrm{rpm}$. The supernatant was collected and filtered. Total phenols of date fruits were determined using Folin-Ciocalteu reagent according to Velioglu et al., (1998). Absorbance was measured at $725 \mathrm{~nm}$ using a UVvis spectrophotometer. The blank contains ethanol and water $(1: 1 \mathrm{v} / \mathrm{v})$ and the reagents. The calibration curve was prepared by measuring the absorbance of known concentration of Gallic acid. Total phenolic contents were expressed as Gallic acid equivalent $(\mathrm{mg} / 100 \mathrm{~g})$ on dry weight basis (Asami et al., 2003).

The determination of total flavonoids was performed according to the colorimetric assay and the results were expressed as $\mathrm{mg}$ Catechin equivalents (CEQ)/100g sample according to Kim et al., (2003). 
General evaluation of Sewy date palm in the tested localities was calculated on the basis of 100 units which were divided among the various yield and fruit properties according to El-Salhy et al., (2016) with simple modification as follows: 20 units for fruit retention, 20 units for bunch weight, 10 units for fruit weight, 10 units for flesh percentage, 10 units for total soluble solids, 10 units for moisture content, 10 units for harvesting date and finally 10 units for total phenols. Each location that gave the best results in any character was given the full mark specified for this character, while each of other tested palms took lower units equal to their quantities.

Data were subjected to statistical analysis according to the procedure reported by Gomez and Gomez, (1984) and Snedecor and Cochran, (1990). Treatments mean were compared by the least significant difference test (L.S.D.) at the 5\% level of probability in the three studied seasons.

\section{Results and Discussions Yield parameters:}

Data presented in Table (2 \& 3) show fruit retention, bunch weight, yield per palm and the harvesting date of Sewy date palm grown under Aswan, El-Kharga, Assiut and AlDakhla climatic conditions during 2015, 2016 and 2017 seasons. It is obvious from the data that the results took similar trend during the three studied seasons.

Data declared that great variability in the fruit retention percentage, bunch weight, yield/palm and harvesting date due to different fruiting location. Results revealed that Al-
Dakhla recorded the highest fruit retention percentage, bunch weight and yield per palm $(75.58 \%-12.34 \mathrm{Kg}$ $123.37 \mathrm{Kg}$ ) while, Assiut recorded lower fruit retention, bunch weight and yield per palm compared to other studied localities. No significant differences were recorded for fruit retention between Al-Dakhla and ElKharga. The recorded fruit retention could be arranged in descending order as follow 75.58, 72.82, 65.70 and $61.15 \%$ as an average in the three studied seasons for Al-Dakhla, ElKharga, Aswan and Assiut area, respectively.

The obtained yield per palm was $(116.63,106.77,123.37$ and $97.83 \mathrm{Kg}$ as an average in the three studied seasons) for Aswan, El-Kharga, AlDakhla and Assiut area, respectively. The increment percentage of yield attained $(18.80,8.94,25.54 \%$ as an average in the three studied seasons) due to those grown in Aswan, ElKharga and Al-Dakhla, respectively, compared to Assiut climatic conditions.

Regarding the harvesting date, the obtained data clearly show that there was a wide variation on harvest date between the tested localities. The fruits started to ripe from the end of August and continued up to the end of September. Data showed that ElKharga and Aswan had been harvested earlier at the end of August, while at Al-Dakhla; the fruit was harvested about two weeks later than ElKharga. On the other hand Assiut was the latest to be harvested during the three studied seasons; such findings could be attributed to the variation on climatic conditions between these localities. 
Table 2. Fruit retention and harvesting date of Sewy date palm under Aswan, ElKharga, Assiut and Al-Dakhla conditions in 2015, 2016 and 2017 seasons.

\begin{tabular}{|l|c|c|c|c|c|c|c|c|c|}
\hline \multirow{2}{*}{ Charac } & \multicolumn{4}{|c|}{ Fruit retained\% } & \multicolumn{5}{c|}{ Harvesting date } \\
\cline { 2 - 10 } Region & $\mathbf{2 0 1 5}$ & $\mathbf{2 0 1 6}$ & $\mathbf{2 0 1 7}$ & Mean & $\mathbf{2 0 1 5}$ & $\mathbf{2 0 1 6}$ & $\mathbf{2 0 1 7}$ & Mean & Earliest \\
\hline Aswan & 67.75 & 63.85 & 65.52 & 65.70 & $3 / 9$ & $28 / 8$ & $1 / 9$ & $1 / 9$ & 23 \\
\hline El- Kharga & 72.69 & 73.10 & 72.66 & 72.82 & $28 / 8$ & $26 / 8$ & $20 / 8$ & $25 / 8$ & 30 \\
\hline Assiut & 60.26 & 61.08 & 62.11 & 61.15 & $21 / 9$ & $25 / 9$ & $26 / 9$ & $24 / 9$ & 00 \\
\hline Al- Dakhla & 75.14 & 76.16 & 75.45 & 75.58 & $8 / 9$ & $10 / 9$ & $12 / 9$ & $10 / 9$ & 14 \\
\hline L.S.D. at 5\% & 3.23 & 3.11 & 2.89 & - & - & - & - & - & - \\
\hline
\end{tabular}

Table 3. Bunch weight and Yield per palm of Sewy date palm under Aswan, ElKharga, Assiut and Al-Dakhla conditions in 2015, 2016 and 2017 seasons.

\begin{tabular}{|l|c|c|c|c|c|c|c|c|}
\hline \multirow{2}{*}{ Charac. } & \multicolumn{4}{c|}{ Bunch weight (kg) } & \multicolumn{4}{c|}{ Yield per palm (kg) } \\
\cline { 2 - 9 } Region & $\mathbf{2 0 1 5}$ & $\mathbf{2 0 1 6}$ & $\mathbf{2 0 1 7}$ & Mean & $\mathbf{2 0 1 5}$ & $\mathbf{2 0 1 6}$ & $\mathbf{2 0 1 7}$ & Mean \\
\hline Aswan & 11.78 & 11.65 & 11.56 & 11.66 & 117.80 & 116.50 & 115.60 & 116.63 \\
\hline El- Kharga & 10.97 & 10.53 & 10.53 & 10.68 & 109.70 & 105.30 & 105.30 & 106.77 \\
\hline Assiut & 9.85 & 9.95 & 9.55 & 9.78 & 98.50 & 99.50 & 95.50 & 97.83 \\
\hline Al- Dakhla & 12.38 & 12.43 & 12.20 & 12.34 & 123.80 & 124.30 & 122.00 & 123.37 \\
\hline L.S.D. at 5\% & 0.38 & 0.31 & 0.28 & - & 4.63 & 5.11 & 4.82 & - \\
\hline
\end{tabular}

\section{Fruit characteristics:}

1- Fruit physical characteristics:

Data of various fruit physical characteristics of Sewy date palm grown under Aswan, El-Kharga, Assiut and Al-Dakhla climatic conditions during 2015, 2016 and 2017 seasons are represented in table $(4 \&$ $5)$. Data revealed that there were significant differences in weight and dimension of fruit and flesh percentage due to different agriculture area. Fruits under Assiut conditions had the heaviest and biggest ones, while Sewy date palm grown under ElKharga conditions gave the lightest and smallest fruit in the three studied seasons. The other two localities (AlDakhla and Aswan) were moderate in fruit weight and size.

Also data indicated that there were significant differences in flesh
$\%$ and moisture content due to those grown under Aswan, El-Kharga, Assiut and Al-Dakhla climatic conditions. Since Aswan recorded the lowest flesh \% and moisture content percentage, while Assiut recorded the highest of them.

On the other hand, there was no significant difference in flesh $\%$ of fruits of Sewy date grown under Assiut, El-Kharga and Al-Dakhla climatic conditions. Results indicated that flesh \% exhibits a similar trend as fruit moisture content due to different agricultural area.

The fruit dimension exhibits a similar trend as fruit weight. The recorded fruit weight could be arranged in descending order as follow 14.59, $12.69,9.64 \& 8.39 \mathrm{~g}$ as an av. In the three studied seasons, due to grow in Assiut, Al-Dakhla, Aswan and El- 
Kharga area, respectively. Then the increment percentage of fruit weight attained $73.89,51.25$ and $14.89 \%$ due to grow under Assiut, Al-Dakhla and Aswan climatic conditions, respectively, compared to El-Kharga climatic conditions.
These results are due to the different climatic conditions of the agricultural areas, where Assiut characterized by an increase in relative humidity and low heat compared to Aswan region where high temperature and low relative humidity.

Table 4. Fruit weight, length and diameter of Sewy date palm under Aswan, ElKharga, Assiut and Al-Dakhla conditions in 2015, 2016 and 2017 seasons.

\begin{tabular}{|l|c|c|c|c|c|c|c|c|c|c|c|c|}
\multicolumn{1}{c|}{ Charac } & \multicolumn{4}{|c|}{ Fruit weight (g) } & \multicolumn{4}{c|}{ Fruit length (cm) } & \multicolumn{3}{c|}{ Fruit diameter (cm) } \\
\cline { 2 - 14 } Region & $\mathbf{2 0 1 5}$ & $\mathbf{2 0 1 6}$ & $\mathbf{2 0 1 7}$ & Mean & $\mathbf{2 0 1 5}$ & $\mathbf{2 0 1 6}$ & $\mathbf{2 0 1 7}$ & Mean & $\mathbf{2 0 1 5}$ & $\mathbf{2 0 1 6}$ & $\mathbf{2 0 1 7}$ & Mean \\
\hline Aswan & 8.90 & 9.59 & 10.44 & 9.64 & 3.23 & 3.28 & 3.30 & 3.27 & 1.90 & 2.06 & 2.04 & 2.00 \\
\hline El- Kharga & 8.45 & 7.78 & 8.93 & 8.39 & 3.12 & 3.09 & 3.19 & 3.13 & 1.81 & 1.71 & 1.93 & 1.82 \\
\hline Assiut & 13.47 & 16.62 & 13.68 & 14.59 & 3.59 & 3.63 & 3.67 & 3.63 & 2.13 & 2.29 & 2.23 & 2.22 \\
\hline Al- Dakhla & 10.92 & 14.36 & 12.80 & 12.69 & 3.46 & 3.48 & 3.44 & 3.46 & 1.98 & 2.15 & 2.12 & 2.08 \\
\hline L.S.D. at 5\% & 0.28 & 0.29 & 0.39 & - & 0.09 & 0.10 & 0.12 & - & 0.05 & 0.06 & 0.06 & - \\
\hline
\end{tabular}

Table 5. Moisture content \% and flesh percentage of Sewy date palm under Aswan, El-Kharga, Assiut and Al-Dakhla conditions in 2015, 2016 and 2017 seasons.

\begin{tabular}{|l|c|c|c|c|c|c|c|c|}
\hline \multirow{3}{*}{ Region } & \multicolumn{5}{|c|}{ Moisture content \% } & \multicolumn{4}{c|}{ Flesh \% } \\
\cline { 2 - 9 } & $\mathbf{2 0 1 5}$ & $\mathbf{2 0 1 6}$ & $\mathbf{2 0 1 7}$ & Mean & $\mathbf{2 0 1 5}$ & $\mathbf{2 0 1 6}$ & $\mathbf{2 0 1 7}$ & Mean \\
\hline Aswan & 14.62 & 14.75 & 13.64 & 14.34 & 83.23 & 83.75 & 82.55 & 83.18 \\
\hline El- Kharga & 15.54 & 15.33 & 14.25 & 15.04 & 85.38 & 86.07 & 84.78 & 85.41 \\
\hline Assiut & 24.83 & 23.67 & 24.11 & 24.20 & 87.68 & 87.27 & 87.31 & 87.42 \\
\hline Al- Dakhla & 17.31 & 16.88 & 15.83 & 16.67 & 87.22 & 87.60 & 85.96 & 86.93 \\
\hline L.S.D. at 5\% & 0.67 & 0.54 & 0.48 & - & 2.34 & 2.65 & 2.53 & - \\
\hline
\end{tabular}

\section{2- Fruit chemical constituents:}

Data presented in tables $(6 \& 7)$ show some chemical properties i.e. TSS, sugar contents, total phenols and total flavonoids of Sewy date palm grown under Aswan, ElKharga, Assiut and Al-Dakhla conditions during 2015, 2016 and 2017 seasons.

It was obvious from the data that results took similar trend during the three studied seasons.

As a general view, data indicated that there are significant differences in TSS, sugar contents, total phenols and flavonoids in different agricultural areas. The highest total soluble solids and sugar contents were recorded on fruits of date palm grown under Aswan conditions. On the other hand, the lowest values were recorded on fruits of date palm grown under Assiut climatic conditions. However, no significant differences were recorded due to grow the Sewy date palm under Aswan, ElKharga and Al-Dakhla climatic conditions. The recorded TSS could be arranged in descending order as follow 70.84, 68.86, 67.94 and 64.49\% as an average of the three studied seasons for fruits from Aswan, El- 
Kharga, Al-Dakhla and Assiut climatic conditions, respectively. The increment of TSS attained 9.85, 6.78 and $5.35 \%$ due to their production under Aswan, El-Kharga and AlDakhla climatic conditions compared to these under Assiut climatic conditions, respectively. Sugar content exhibit similar trend to the total soluble solids, that is due to the effect of different production localities.

On the other hand, the obtained results indicated that there were significant differences in total phenols and flavonoids content among studied localities during the three studied sea- sons. Assiut recorded the highest total phenolic content during the three studied seasons, while El-Kharga recorded the highest flavonoids content. On the other hand, Aswan recorded the lowest value of total phenolic and flavonoid content during the three studied seasons. These results are due to the different climatic conditions of the agricultural areas, where Assiut characterized by an increase in relative humidity and low heat compared to Aswan region where high temperature and low relative humidity are present.

Table 6. Total soluble solids, total phenols and total flavonoides of Sewy date palm under Aswan, El-Kharga, Assiut and Al-Dakhla conditions in 2015, 2016 and 2017 seasons.

\begin{tabular}{|c|c|c|c|c|c|c|c|c|c|c|c|c|}
\hline \multirow{2}{*}{ Charac } & \multicolumn{4}{|c|}{ TSS \% } & \multicolumn{4}{|c|}{ Total phenols (mg/100g) } & \multicolumn{4}{|c|}{ Total Flavonoides(mg/100g) } \\
\hline & 2015 & 2016 & 2017 & Mean & 2015 & 2016 & 2017 & Mean & 2015 & 2016 & 2017 & Mean \\
\hline Aswan & 69.12 & 71.18 & 72.23 & 70. & 297.8 & 32 & 286.84 & & 1 & 38.78 & & \\
\hline El- Kharga & 67.54 & 68.83 & 70.22 & 68.86 & 332 & 346 & & & & 11 & & \\
\hline & & & & & & & & & & & & \\
\hline Al- Dakhla & 66.42 & 67.90 & 69.51 & 67.94 & 338 & 345 & 325 & 336.52 & 183 & 189 & & 183.71 \\
\hline L.S.D. at 5\% & 2.11 & 2.38 & 2.19 & - & 11.89 & 10.96 & \begin{tabular}{|l|l|}
9.74 \\
\end{tabular} & - & 7.35 & 8.14 & 7.59 & - \\
\hline
\end{tabular}

Table 7. Total sugars $(\%)$, reducing sugars $(\%)$ and non -reducing sugars $(\%)$ of Sewy date palm under Aswan, El-Kharga, Assiut and Al-Dakhla conditions in 2015, 2016 and 2017 seasons.

\begin{tabular}{|c|c|c|c|c|c|c|c|c|c|c|c|c|}
\hline \multirow{2}{*}{ Region } & \multicolumn{4}{|c|}{ Total sugars \% } & \multicolumn{4}{|c|}{ Reducing sugars \% } & \multicolumn{4}{|c|}{ Non- reducing sugars $\%$} \\
\hline & 2015 & 2016 & 2017 & on & 15 & 2016 & 2017 & Mean & 2015 & 2016 & 2017 & Mean \\
\hline Aswan & & & & & & & & & & & & \\
\hline & & & & & & & & & & & & \\
\hline & 68 & 54. & & & 3.75 & & & & 8.9 & & & 9.13 \\
\hline & & & & & 50.19 & & & 50.90 & 10.38 & & & 10.28 \\
\hline & 1.68 & 1.55 & 1.78 & -1.0 & 0.96 & 0.89 & 1.15 & & 0.38 & 0.46 & 0.36 & \\
\hline
\end{tabular}

\section{C- General evaluation:}

Data in Table (8) show the numerical evaluation of Sewy date palm under Aswan, El-Kharga, Assiut and Al-Dakhla conditions. The evaluation showed that Al-Dakhla recorded the highest units (91.39) of the total score, while Assiut recorded the lowest score of yield and fruit quality as follow: Al-Dakhla (91.39), El-Kharga (91.14), Aswan (88.94) and finally Assiut (77.06).

In general view data indicated that Sewy date palm that grown under El-Kharga climatic conditions recorded the highest yield parameters unites (46.58), followed by AlDakhla (44.67 units), moreover, un- 
der Al-Dakhla climatic conditions recorded the highest fruit quality

(46.72 units) compared to other studied localities.

Table 8. General evaluation of Sewy cultivar grown under different climatic conditions as average of the studied seasons.

\begin{tabular}{|c|c|c|c|c|c|c|c|c|c|c|c|}
\hline \multirow[b]{2}{*}{ Characters } & \multicolumn{4}{|c|}{ Yield components } & \multicolumn{6}{|c|}{ Fruit quality } & \multirow[b]{2}{*}{$\begin{array}{c}\text { G. } \\
\text { total }\end{array}$} \\
\hline & $\begin{array}{c}\text { Fruit } \\
\text { retention }\end{array}$ & $\begin{array}{c}\text { Bunch } \\
\text { weight } \\
\text { (kg) }\end{array}$ & $\begin{array}{c}\text { Harvesting } \\
\text { date }\end{array}$ & Total & $\begin{array}{c}\text { Fruit } \\
\text { weight } \\
\text { (g) }\end{array}$ & $\begin{array}{c}\text { Flesh } \\
(\%)\end{array}$ & $\begin{array}{c}\text { Moisture } \\
\text { content } \\
(\%)\end{array}$ & TSS & $\begin{array}{c}\text { Total } \\
\text { phenols }\end{array}$ & Total & \\
\hline Score units & 20 & 20 & 10 & 50 & 10 & 10 & 10 & 10 & 10 & 50 & 100 \\
\hline Aswan & 17.38 & 18.89 & 7.67 & 43.94 & 6.60 & 9.51 & 10.00 & 10.00 & 8.89 & 45.00 & 88.94 \\
\hline El-Kharga & 19.27 & 17.31 & 10.00 & 46.58 & 5.75 & 9.77 & 9.53 & 9.72 & 9.79 & 44.56 & 91.14 \\
\hline Assiut & 16.18 & 15.85 & 0.00 & 32.03 & 10.00 & 10.00 & 5.93 & 9.10 & 10.00 & 45.03 & 77.06 \\
\hline Al- Dakhla & 20.00 & 20.00 & 4.67 & 44.67 & 8.70 & 9.94 & 8.60 & 9.59 & 9.89 & 46.72 & 91.39 \\
\hline
\end{tabular}

These results might be attributed to differences in climatic conditions (temperature and relative humidity) between the tested localities. In Aswan where high temperature and low relative humidity are present, the T.S.S. and total sugars recorded the highest values $(70.84,63.68)$, while moisture content \% recorded the lowest one (14.34). On the other hand, Assiut (lower temperature and higher R.H.) recorded the lowest values of T.S.S. (64.49), total sugars $(54.08 \%)$ and the highest value of moisture content \% (24.20). These results are in harmony with those obtained by El-Said Samra 1978, Nour 1986, Abdalla et al., (1990, 1991 and 1996), Hussein et al., 2001, Soliman 2002 and El-Salhy et al., (2004).

Abdalla et al., (1996) stated that climatic conditions temperature and relative humidity were the most important factors affecting fruiting of date palms.

As is evident from the foregoing results, the climatic conditions of AlDakhla and El-Kharga Oasis are ideal climatic conditions for the cultivation and productions of Sewy date palm.

\section{References}

Abdalla, M.Y, Said, G.A. and El-Masry H.M. (1990). Effect of planting zone on major characteristics of Zaghloul date cultivar. Zagazig.J. Agric., Res., 17 (5 A): 1621- 1630.

Abdalla, M.Y, Bastawros, M.B. and Haggag, L.F. (1991). Effect of plantation zone on bunch and fruit properties of Samany dates. Zagazig. J. Agric., Res., 18(1): 135-143. Abdalla, M.Y., A.M., Sabour, F.B. ElMakhtoum and A.M. Ahmed. (1996). Effect of some environmental conditions on vegetative, yield and fruit properties of Sewy date cultivar. Zagazig Agric. Res. 23 (1): 132-143.

Al-Rawahi, A.S.; S. Kasapis and I.M. Al-Bulushi. (2005). Development of a date confectionary: Part 1. Relating formulation to instrumental texture. Intr. J. Food Prop. 8:457468.

Asami, D. K., Hong Y. J., Barrett, D. M. and Mitchell, A. E. (2003). Processing induced changes in total phenolics and procyanidins in Clingstone peaches. Journal of the Science of Food and Agriculture 83: 56-63.

Association of Official Agricultural Chemists. (1985). Official Methods of Analysis, AOAC. 14. Ed. Pp. 496-500 Benjamin Franklin, Station Washington D.C., U.S.A.

El-Said Samra, N.R. (1978). Physiological studies on date fruits. M. Sc. 
Thesis Hort. Fac. Agric. Ain Shams Univ. Cairo.

El-Salhy, A.M., Ibrahim, R.A., Gadalla, E.G.and Khalil, H.K.H. (2016). Evaluation of some seeded dry date palm grown under Aswan climatic condition. Assiut J. Agric. Sci.,(47) No.(4: 136-155).

El-Salhy, A.M., K. Ahmed and E.F. Badwy.(2004). Physiological studies on fruit development of some date cultivars under Assiut condition. Workshop on Agric. Develop. In Arab Nation Obstacles \& Solutions. Jan. 20-22, Assiut, Egypt, pp. $175-191$.

Gomez, K.A. and Gomez A.A., (1984). Statistical procedures for agricultural research, $\left(2^{\text {nd }}\right.$ ed. $)$ NewYork (USA): John wiley, p: 680.

Hussein, A.A.M., Attia, N.M.I. and Osman, S.M. (2001). Survey and evaluation of fruit cultivars for some species grown under Siwa Oasis. 11. Date palm Annal of Agric. Sci., Moshtohor, 39(2): 12651278

Jaradate, A.A. and Zaid, A. (2004). Quality traits of date palm fruits in a center of origin and center of diversity. International J. of Food, Agric. and the Environment, 2 (1): 208-217.

Kassem, H.A. (2012). The response of date palm to calcareous soil fertilization. Journal of Soil Science and Plant Nutrition, 12 (1): 45-58

Kim, D.O., Jeong, S.W. and Lee, C.Y. 2003. antioxidant capacity of phenolic phytochemicals from various cultivars of plums" Food chemistry, 81- 321-326.

Mohamed, S, G., Abd-Allah, B.M. and Mostafa, F.M.A. (2004). Comparative study on some Iraqi date palm grown under middle and upper Egypt climatic conditions. Egypt. J. Appl. Sci., 19:339-354.
Nixon, R.W. and J.B. Carpenter. (1978). Growing dates in the United States. United States Department of Agriculture Bulletin no. 207, U.S. Department of Agriculture, Washington, DC.

Nour, G.M., Khalifa, A.S., Hussein, A.A.M. and Moustafa, A.A. (1986). Studies on the evaluation of fruit characteristics on nine dry date palm cultivars grown at Aswan. The second symposium on date palm, King Faisal Univ., AllHassa, Saudi Arabia pp. 163-171.

Rygg, G.L. (1971). Comparison of Heat of Indio, California with that of Biskra and Touggourt, Algeria and its effect on Deglet Noor date quality. Date Grower's, Inst. Rept. 48:23.

Selim, H.H.A., El-Mahdi, M.A.M. and EI-Hakeem, M.S. (1968). Studies on the evaluation of fifteen local date cultivars grown under desert condition in Siwa Oasis, U.A.R. Bull. De desert d' Egypt (1): 137155.

Snedecor, G.W. and W.G. Cochran. (1990). Statistical methods $7^{\text {th }}$ Ed. Iowa State Univ. Press. Ames.

Soliman, S.S. (2002). Studies on the evaluation of fruit characteristics of Samany date palm grown in Aswan. J. Agric. Sci. Mansoura Univ., 27(8): 5421-5428.

Velioglu, Y. S., Mazza, G., Gao, L. and Oomah, B. D. (1998). Antioxidant Activity and Total Phenolics in Selected Fruits, Vegetables, and Grain Products. J. Agric. Food Chem.46: 4113-4117.

Wrigley, G. (1995). Date palm (Phoenix dactylifera L.) palmea pp. 399403. In J. Smarrtt and N.W. Simmonds (eds), Evaluation of crop plants. $2^{\text {nd }}$ edition, Longman, UK. 


\section{تقييم انتاجية نخيل البلح السيوي تحت ظروف مناخية مختلفة}

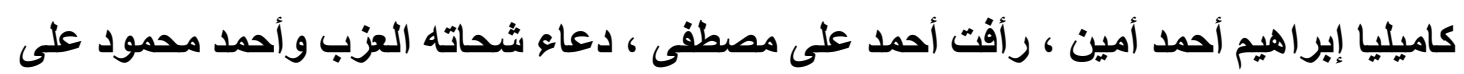

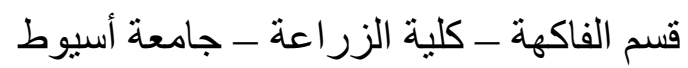

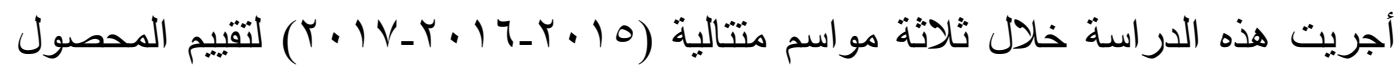

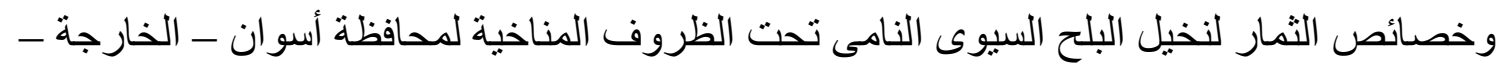
أسيوط - الداخلة.

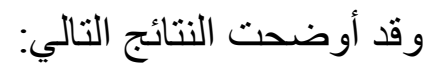

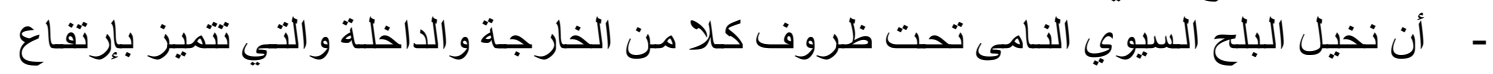

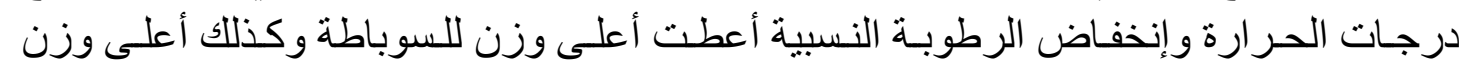

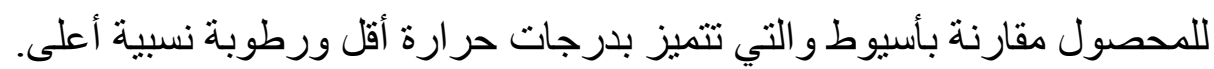

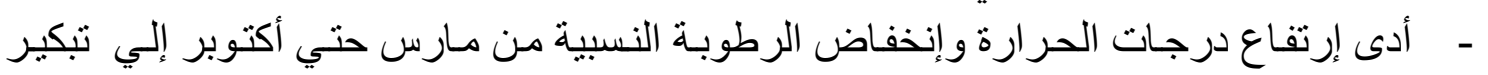

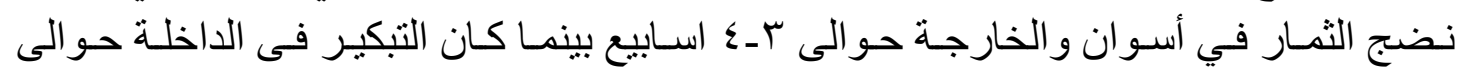
أسبو عين مقارنة بأسيوط. - سجلت أسيوط و الداخلة أعلي قر اءة لأبعاد الثمار ووزنها ونسبه اللحم مقارنـة بالمو اقع الأخرى

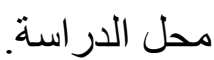
- سجلت ثمار البلح السيوى أعلي نسبة من المواد الصلبة الذائبة الكلية ومحتوى السكريات و أقل الطبل

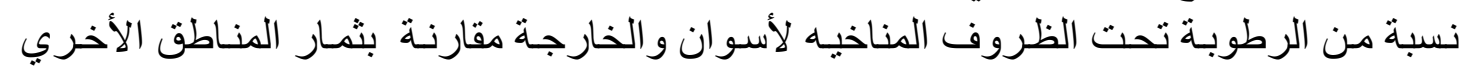

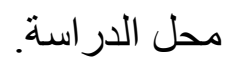
- لم تسجل فروق معنوية فى صفات الثمار الكيمائية تحت ظروف واحتى الداخلة و الخارجة بل

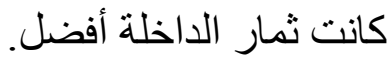

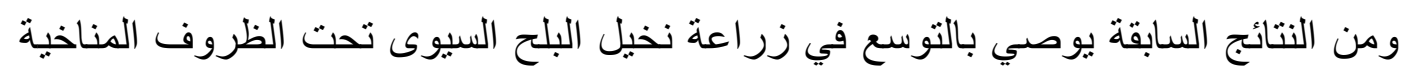

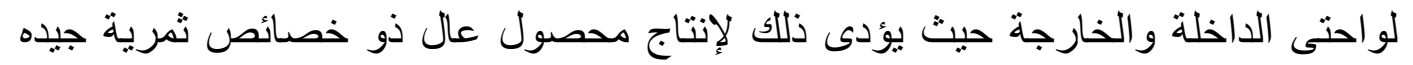

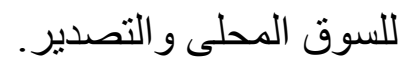

